\title{
Tourist Art Packaging Randai Performance in Seribu Rumah Gadang Area Jorong Lubuk Jaya Nagari Koto Baru, Solok Selatan Regency, West Sumatra
}

\author{
Marzam $^{1}$, Darmawati ${ }^{2}$, Herlinda Mansyur ${ }^{3}$ \\ ${ }^{1}$ The Lecturer of Arts, Drama, Dance and Music (Sendratasik) Education Study \\ Program of FBS, Universitas Negeri Padang, Indonesia. \\ e-mail: marzam1962@fbs.unp.ac.id \\ ${ }^{2}$ The Lecturer of Arts, Drama, Dance and Music (Sendratasik) Education Study \\ Program of FBS, Universitas Negeri Padang, Indonesia. \\ e-mail: darmawati@fbs.unp.ac.id \\ ${ }^{3}$ The Lecturer of Dance Education Study Program of FBS, Universitas Negeri \\ Padang, Indonesia. \\ e-mail: lindamansyur@fbs.unp.ac.id
}

\begin{abstract}
Randai is a traditional Minangkabau art that presents a combination of literary, dance and music. The essence of randai presentation is as a medium to convey kaba (folklore) through gurindam or poems sung, and galombang (dance) originating from Minangkabau martial arts movements. Randai performance is good for 2 to 3 hours, depending on the kaba or folklore delivered. This article is prepared based on the research of randai performances in the context of tourism in Kawasan Seribu Rumah Gadang Jorong Lubuk, Jaya Solok Selatan District, West Sumatra. Research on this was carried out using qualitative methods. The data was collected through literature study, observation, interviews, and recording. As a tourist attraction, the randai shown is randai which presents compaction of Bujang Selamat folklore, which begins with talempong music as an introduction to anak randai to the performance arena, followed by sambah, plate dance, galombang, compaction of bujang salamat folklore, then ends with sambah. All randai offerings as tourist attractions last for 20 to 25 minutes.
\end{abstract}

Keywords: randai performances, tourist attractions.

\section{Introduction}

Solok Selatan is known as Alam Surambi Sungai Pagu (see Maestro Esy; Marzam, 2018: 1), formerly known as the Kingdom of Sungai Pagu which is the Ikua Darek of the Minangkabau Kingdom in Pagaruyung. Firdaus, (2009) in his report revealed that, several historical heritages can still be traced and interesting to further research, such as the presence of Puti Sigintir Palace, Tuangku Rajo Malenggang Palace and Rajo Putiah in Pasir Talang, and Tuanku Rajo Bagindo Palace in Balun. Historical relics during the early days of Islam in Minangkabau such as Kurang Aso 60 Mosque in Pasir Talang and the Great Mosque and surau Menara in Koto Baru. With these uniqueness, Alam Surambi Sungai Pagu will now become the world's cultural heritage.

One of the locations of the existence of the cultural heritage is in Nagari Koto Baru. Nagari in Sungai Pagu Subdistrict, Solok Selatan Regency, have indigenous villages. The location is $\pm 150 \mathrm{~km}$ overland journey from Padang City. Entering Nagari Koto Baru, you can witness the past Minangkabau village. Hundreds of Minangkabau traditional houses or Rumah Gadang on the left and right along the village road are mostly still maintained. The sight of these artistic bagonjong houses is able to eliminate fatigue after taking a long journey which takes around 3.5 - 4 hours from Padang City.

It is not difficult to find an area that had been used as a shooting location for the film Dibawah Lindungan Kabah which was taken from Buya Hamka's novel, because it was near the main road of South Solok which connected 
Padang City with Kerinci Regency, Jambi Province. The giant sign reads Kawasan Saribu Rumah Gadang next to the entrance of Koto Baru Grand Mosque. Because of its artistic location, this area was also used as the location of a television movie (FTV) entitled "Calon Istri yang Terzalimi" and aired on one national private television.

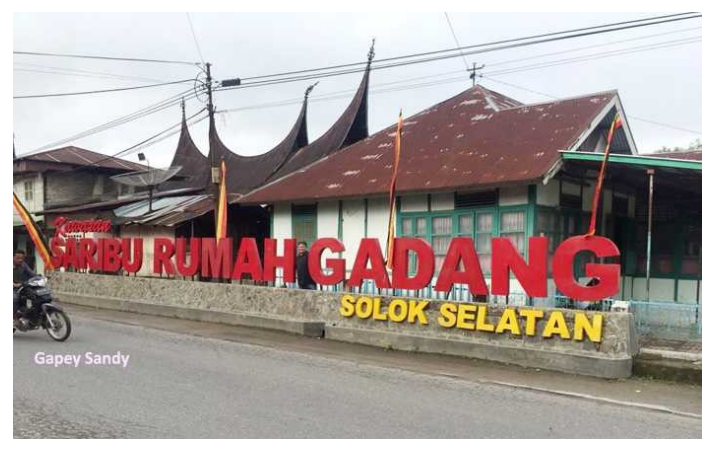

Figure 2

Adat Saribu Rumah Gadang Tourism Area (SRG) in Jorong Bariang Rao-Rao, Kenagarian Koto Baru, Sungai Pagu District, Solok Selatan Regency.

(Picture by: Gapey Sandy)

(source: https://www.kompasiana.com/gapey-sandy/5a9e4ebe5e13732d1859c892/

kawasan-seribu-rumah-gadang-pesona-peradaban-nenek-moyang?page=all)

After entering the gate, a row of rumah gadang on the left and right of the road seemed to be a posse and ready to welcome visitors who wanted to enjoy the views of the Minangkabau traditional house. To be able to enjoy the beauty of rumah gadang, visitors or tourists can walk around the area. According to the Head of Culture at the Solok Selatan Culture and Youth Tourism Office, Ferry Yuredi, in the area in Sungai Pagu Subdistrict, there are at least 174 houses in various forms. But he could not confirm the model of any type of house in the area even though it is inhabited by a number of tribes in the Minangkabau. "Further research is still needed to find out the models of existing rumah gadang in Kawasan Seribu Rumah Gadang," he said.

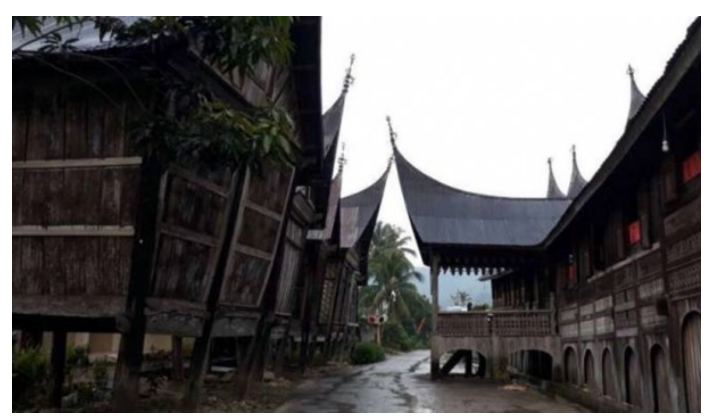

Figure 3

Maram Rumah Gadang Gajah Maram, which was built in 1794 ago.

Rumah Gadang Kaum Suku Melayu Buah Anau belongs to Datuk Lelo Panjang

located in Jorong Lubuk Jaya, Nagari Koto Baru, Sungai Pagu District

Solok Selatan Regency

(Source: Marzam 2018 Documentation)

A number of tribes settled in the area, such as the Malays, Bariang, Durian, Kampai, Panai, Tigo Lareh, Koto Kaciak, and Sikumbang. Each tribe has a Rumah Gadang. The diversity of tribes that inhabit the Saribu Rumah 
Gadang area, shows that in that area it has maintained tolerance since ancient times. Rumah gadang, especially the traditional rumahgadang, are currently uninhabited. The houses are used only for traditional events.

One of the daughters of the Indonesian proclamator, Bung Hatta, namely Meutia Farida Hatta Swasono, had set foot in Nagari in 2008. At that time, Sri Edi Swasono's wife served as State Minister for Women's Empowerment during President Susilo Bambang Yudhoyono. Meutia Hatta gave the nickname Solok Selatan as the Nagari Seribu Rumah Gadang because there are still many houses that are typical of gonjong in the area. Seribu Rumah Gadang area, has entered into the tourism development area in the district which was expanded in 2004 and then from Solok district.

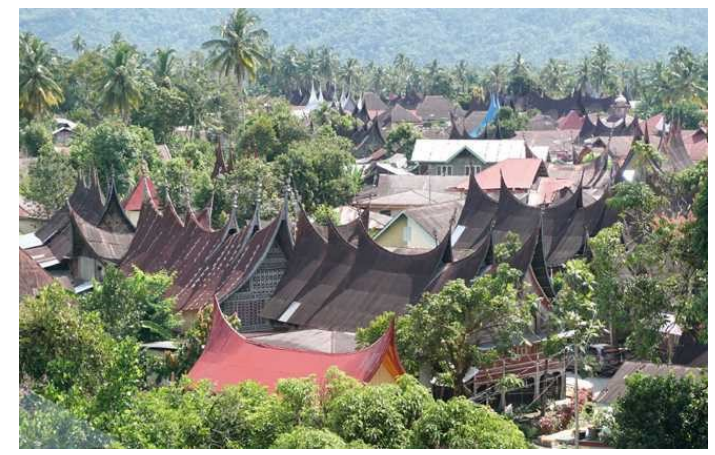

Figure 4

Seribu Rumah Gadang Area Nagari Koto Baru

Source: (ciptakarya.pu.go.id)

Traditional houses belonging to these tribes since approximately 2 years ago have become tourist destinations that are now known as Seribu Rumah Gadang Area. In the area, several traditional houses are used as home stays. Tourists who visit there can rent rooms in Rumah Gadang at quite affordable prices. With a price of 200 thousand rupiah per night per head, it includes dinner and breakfast as well as culinary specialties of the Solok Selatan region. At the request of a travel agency that brings tourists to the area, tourists are also treated to various traditional art attractions. Traditional art performances are held at 9-10 am. Of course treats traditional arts that have been packaged for the needs of tourists, who do not have time to watch every attraction they enjoy. Some types of traditional arts that become tourism potentials are presented at that time, including tempurung dance, gandang sarunai, talempong pacik, and randai.

Initially some traditional arts that were presented as tourist attractions in the Seribu Rumah Gadang Area, are arts that are usually presented in alek nagari events of Sungai Pagu, such as Batagak Pangulu, weddings, turun mandi, and so on. This art is not a commodity that is packaged for spectator tourism. Given the development of the world of tourism that occurs in their environment and the economic potential that may be achieved, the community at the instigation of the Regional Government makes new commodities or packaging for their traditional arts that are specifically presented for the spectacle of tourists, as expressed by Manuati (2006) in (Anjasuari, Ni Wayan Trisna; Sumadi \& I Ketut Arta, 2017) that, traditional performing arts become a commodity that has never been a commodity before and then presented to tourists to watch. Likewise, the Randai of the Koto Baru community in Solok Selatan Regency, which was originally only presented in the alek nagari events, is currently packaged for the benefit of tourism commodities in Seribu Rumah Gadang Area.

In connection with the forms of spectacle that is packaged for tourist purposes, Graburn who borrows the concept of J. Maquet (Kuswarsantyo, 2007: 122) says that, art products based on the type of audience are divided into two categories:

1. Art that is indeed made for the benefit of the community (art by destination)

2. The art created for other people (visitors / tourists) is called art by metamorphosis.

Tourism art is categorized into the second one. Thus the art of tourism must be able to adjust to the tastes of the audience. The second category art is also called the art of acculturation. Besides that, because traditional 
characteristics are always present in the art of this second group, but the sacred and magical values have been removed, the art of acculturation is called pseudo traditional arts.

Soedarsono (Kuswarsantyo, 2007: 122) in addition to describing the presence of art tourism as a result of the presence of the tourism industry, also provides advice on how we can cope so that the art domain should not be swallowed by the tourism industry domain. Borrowing the diagram of Theodore M. Greene, Soedarsono suggests like the diagram below.

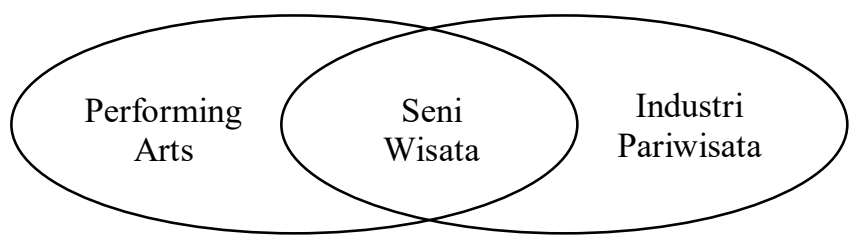

Figure 5

Optimization diagram of art development which will not damage the performing arts ecosystem

Looking at the comparison between the two domains, optimizing the development of performing arts for the benefit of tourists should apply the concept that has been put forward by Soedarsono above. Thus the development of tourist destinations will not damage the performance art ecosystem itself as an art of ancestral tradition that must be preserved.

This article tries to see how far the concept offered by Soedarsono above is applied in Randai art as a tourist art for tourists visiting Seribu Rumah Gadang Area of Jorong Lubuk Jaya, Nagari Koto Baru, Solok Selatan Regency, West Sumatra.

\section{Method}

This article was written based on the results of research with the title Randai Performance in Tourism Context in Seribu Rumah Gadang Areas Solok Selatan District West Sumatra. Research on the object was carried out using qualitative methods that utilize descriptive, analytical and interpretive approaches. According to Bogdan and Taylor (in Moleong, 2012: 4) qualitative research as a procedure that produces descriptive data in the form of written or verbal words from people and observable behavior. In this case, it will collect written words or verbal and behavioral behavior of people involved both directly and indirectly in the activities of randai packaging performances in the Seribu Rumah Gadang tourism area, Lubuk Jaya Village, Nagari Koto Baru, Sungai Pagu District, Solok Selatan Regency.

The data was collected by interviewing informants who consisted of studio leaders, tuo randai, randai players, as well as community members around Saribu Rumah Gadang area who were considered to know much about the randai performance activities. For documentation of data collection events such as interviews, randai performances, and other evidence enshrined with audio and video recording techniques. In addition, documentation techniques are also utilized, especially to obtain evidence about Saribu Rumah Gadang area as a cultural tourism area in Solok Selatan Regency.

Data analysis is done by steps of identification, classification, tabulation and interpretation. Identification activities were carried out to find aspects that were able to provide attraction in a randai performance. Identification results are grouped according to research problems, namely randai performances as tourist attractions. The next step is data interpretation. This activity is carried out based on observations (live performances and video recordings), interviews, and notes during the research process.

\section{Results and Discussion}

\section{Randai Traditional Art}

Randai is a traditional Minangkabau art in the form of a [traditional] theater. Randai performances take place on an arena stage in a circular motion by a number of male and/or female players. While singing - which was led by a man commonly called a gore craftsman, the players moved in a circle to perform the movements of martial arts skillfully. In addition to the element of motion (dance), as a form of traditional theater, Randai also has elements of 
music (vocal and instrumental), story elements, as well as elements of play (acting and dialogue). All of these elements constitute an inseparable unity with each other. With musical accompaniment that supports the atmosphere, in addition to the form of dialogue, stories or introductory stories in each scene delivered in the form of a strand that is sung (sung).

Explanation of the existence of Randai as a performing art in the social-cultural activities of the Minangkabau community is described in great detail and interesting by Wendy HS. Referring to Zulkifli (1994), (Wendy Hs., 2014: 38-39) explains that:

... has been rearranged the history of Randai's existence in the Minangkabau community in West Sumatra in the following periodization, namely: (1) The Minangkabau Natural Period, can be marked from the beginning of the Minangkabau civilization, until the 17th century. This period begins with the existence of one part in the practice of silek learning which deliberately demonstrates the order of the steps (body movements as silek moves) colossally / together in a circle or circular formation. Usually the practice of silek learning was held in the surau courtyard every night, on certain days, as a form of togetherness and the introduction of all students, which was also attended by cross generations who had learned silek in the surau. The colossal / together practice of silek learning slowly developed into a spectacle. This form of spectacle originated from the development of a stage arrangement (body movements as silek moves) together in the formation of the circle, accompanied by musical compositions from the sound of claps, fragments of drumming, and accompaniment of a musical instrument of talempoang... (more details see Wendy Hs., 2014).

Furthermore, the development of randai until now has been contradicted by the presentation of folklore such as, Malin Deman, Anggun nan Tongga, Cindua Mato, and other folklore.

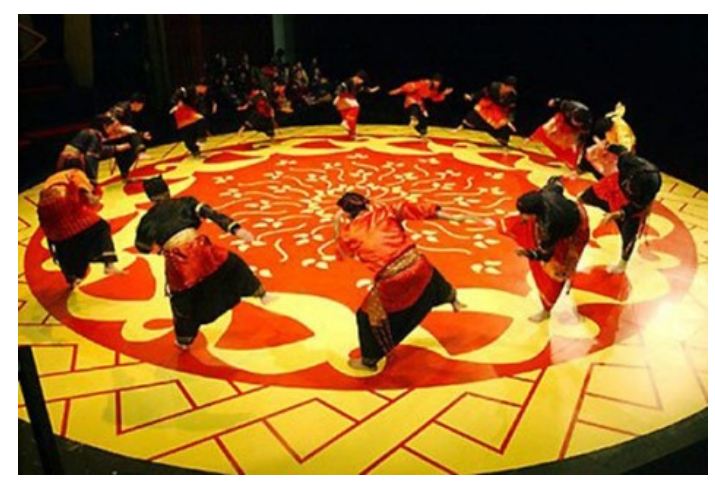

Figure 6

Randai Performance at the Siti Nurbaya Festival (4th FSN)

(Source: http://sumbar.antaranews.com/berita/116499/ traditional arts randai-meriahklan-fsn-di-padang)

Observing randai performances in cultural festivals held by Taman Budaya of Padang City, as well as randai performances at the Padang City Siti Nurbaya Festival, it is seen that conventionally there are rules related to randai structures. Every randai group - from the various regions in Minangkabau who performed, always started the performance, randai entered the arena with galombang movements accompanied by dendang dayang daini. Galombang is presented in pencak motion while walking to form a circle formation (legaran), accompanied by the sound of hep ... ta ... hep ... ta ... hep ... ta ... tukang goreh (leader in galombang player group). The first leg usually ends with a two-line formation that goes up to enter the section. In connection with this (Indrayuda; Muasri \& Sexri Budiman, 2013: 79) explains that, sambah is the opening structure to the course of the story. In the addition, the speech was delivered in the form of plots which essentially conveyed a request for permission to the audience of the randai performance audience that they would present a randai performance, as well as in the addition, an apology was delivered if there was a mistake or mistake that could offend the audience of the randai show. This addition section is accompanied by dendang dayang daini and simarantang randah.

Furthermore, it comes to the presentation of the structure of the story in randai. The story is narrated through poetry sung by the singer with saluang music accompaniment. In this part of the story, like most drama scenarios, 
there are characterizations according to the story presented. In this part of the story, legaran presented serve as partsection chapters in randai performances. Apart from that, legaran also functions as an introduction or description of the stories that will be presented by the leading figures in the next section. (See Indrayuda; Muasri \& Sexri Budiman, 2013).

The end of the randai show is back to sambah. Galombang motion in a circle formation in the closing part is accompanied by pasambah greeting which is conveyed through dendang simarantang tinggi and is closed with the presentation of music talempong pacik, gandang, and sarunai.

Traditionally, the presentation of randai in various socio-cultural activities of the community, a story presented in the randai show, for example the Cindua Mato story, can last for 2-3 hours.

\section{Randai in Sungai Pagu Solok Selatan}

In Alam Surambi Sungai Pagu, according to information from Tuo Randai (Randai Instructor) Zulkifli aka Si Jun Medan (63 years), (Interview, July 14, 2018), Randai has long been in Sungai Pagu. Zulkifli knows the existence of Randai in his village based on his grandfather's story. Grandfather Zulkifli has known the existence of Randai since he was still not married, but Zulkifli did not get any information or could not explain since when Randai developed in Alam Surambi Sungai Pagu.

Based on the period of development of the randai in Minangkabau that was described (Wendy Hs., 2014), that randai has been shown on Sungai Pagu since the Dutch Colonial Age. The randai show was proven by Wendy Hs. with a photograph explaining randai activity of Minangkabau people at the Queen's Day, held in the yard of the home of a Dutch controlman in the Muaro Labuah area, Solok Selatan district, March 31, 1916. In the photo information was not explained whether the randai performances were performed by anak nagari Alam Surambi Sungai Pagu, or the randai show is played by randai groups who come from other regions in Minangkabau. Thus it cannot be ascertained whether randai art has lived, grown, and developed in the socio-cultural activities of the Alam Surambi Sungai Pagu community in the colonial period.

Seeing the musical instruments used (as seen in the photo), a pair of gandang commonly played in gandang sarunai music performances (traditional music native to the Alam Surambi Sungai Pagu community), it could have been that at that time randai art had developed in Sungai Pagu, but the occupation period Japan is repressive of the existence of Nagari and tends to result in Randai performance in unproductive conditions (see Wendy Hs., 2014: 40), even for various reasons it may be able to turn off the existence of Randai art in Surambi Sungai Pagu.

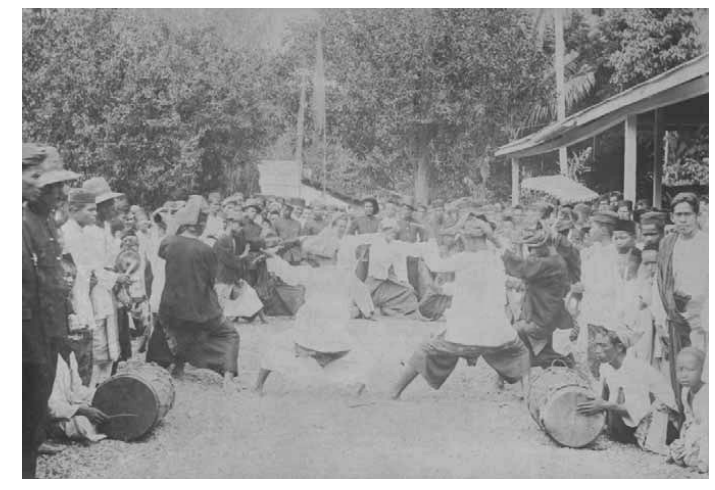

Figure 7

Randai activities of the Minangkabau community on the Queen's Day held in the courtyard of the home of a Dutch controlman in the Muaro Labuah area Solok Selatan Regency, March 31, 1916.

(in Wendy Hs, 2014; Source: Photo Collection of KITLV Leiden, Netherlands, 2013)

Furthermore, according to Zulkifli, randai art once again became the concern of the Surambi Sungai Pagu people when a nomad from Saok Laweh in Solok Regency in 1970 taught Randai to anak nagari Sungai Pagu, but it was 
not very popular. In 1973, nomads from Tanjung Simalidu named Buri were more able to embrace anak nagari for more intense learning randai. Zulkifli as one of tuo randai at Sungai Pagu inherited the randai art from Buri nomads from Tanjung Simalidu. When studying Randai to Buri, Zulkifli was 18 years old. Since then, Randai art has been favored by the Sungai Pagu community.

Kaba (story) which is often performed in the randai anak nagari Sungai Pagu show is Kaba Bujang Selamat. Like most randai shows in Minangkabau, the randai Bujang Selamat show begins with the talempong pacik performance by the randai children. This talempong pacik performance can be meaningful as a notification to the audience that the randai show will begin immediately.

The voice of hep ... ta ... hep ... ta ... hep ... ta ... from tukang gore, led the players to enter the performance arena. Randai players enter the performance arena with talempong pacik accompaniment until they form a circle formation in the middle of the arena. Furthermore, randai players with the accompaniment of dendang dayang daini presented the sambah section which aimed to apologize to the nagari leader, niniak mamak, cadiak pandai, and audiences who were present to watch the randai show. The presentation of the sambah section is finished, followed by the story section which is delivered by gurindam by the drummer accompanied by galombang motion by randai players. In the first legaran (the presentation of galombang in a circle formation), the gurindam which was sung in the simarantang song usually contained an introduction to the story before the characters in the story took their role. Legislation in randai offerings can be meaningful as an introduction to round by round of the stories presented in the randai show. Usually, a good story takes place in 5 to 8 rounds, in which each round lasts for 20 to 25 minutes depending on the plot or scenario of each round. Finally, the randai show was closed with sambah accompanied by simarantang dendang tinggi, followed by talempong pacik performance to take the randai players off the stage.

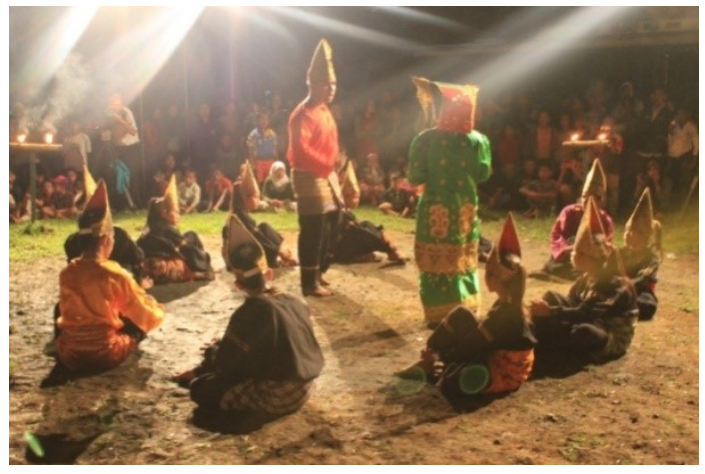

Figure 8

Scene of Bujang Selamat on dialogue with Puti Linduang Bulan in one of the rounds of the randai Bujang Selamat story by the Madang Saiyo Group

Mudiak Lolo, Muara Labuh, Nagari Koto Baru, Solok Selatan Regency.

(Documentation: Ibuk Yusnidar, source of research February 2018)

\section{Randai Tourism Art Packaging in Seribu Rumah Gadang Area}

Traditional arts are usually presented in the social cultural activities of Minangkabau people such as, in batagak panghulu events, weddings, turun mandi, khitanan, and so on for a long time ( 2 to 3 hours) and even traditional arts are presented starting from ready when the prayer isha 'ends until the time of the morning prayer. It is not possible to present traditional arts with a long duration as a tourist art. Tourists who visit a tourist destination and watch art shows, of course have limited time. Therefore, managers of tourist attractions and art groups as supporters of the existence of tourist destinations must have tips for packing their traditional arts to make them more attractive, especially not taking up much time for tourists visiting and watching art.

The main thing that artists must consider when making art of packaging for tourist consumption is not to damage the performance art ecosystem itself as an art of ancestral heritage that must be preserved (Soedarsono in 
Kuswarsantyo, 2007: 122). Thus, as suggested by Kuswarsantyo, 2007: 123) the strategic concept in presenting a tour show is the pseudo traditional arts or imitation traditional art proposed by J. Maquet. Related to the tourism and performing arts business, Spillane (1971) in (Kuswarsantyo, 2007: 123) states that disclosing forms of tourism packaging art must be anticipated with proper management of management. Thus, it is not sacrifice the essential elements in the packaging.

Randai art tourism packaging in Seribu Rumah Gadang Area can be said to be an imitation of traditional randai. Based on observations and interviews with Zulkifli aka Si Jun Medan (July 14, 2018), Randai Packaging remains in the same structure as traditional Randai, which is different from the storytelling and stories presented. Traditional Randai which presents the story of Bujang Selamat takes place in 6 rounds, while randai art tourism packaging is presented in one round. According to the informant, the essence of randai packaging does not lie in the integrity of the presentation of the story, but rather in the integrity of the presentation of the randai structure which consists of the opening section (with a little element of creativity), sambah, story (compaction), and closing cover. In this case, the randai of art tourism packaging in the Seribu Rumah Gadang Area begins with traditional dance as an opening and at the same time leads the randai players with the talempong pacik accompaniment to the performance arena (the yard of rumah gadang Gajah Maram). To enter the sambah part, galombang is presented with accompaniment of dendang dayang daini until the randai players form a circle formation. The next structure is legaran to deliver to the presentation section of the Bujang Selamat story, which is no more than 5 minutes, the last legaran of the presentation is to deliver to the closing sambah accompanied by dendang simarantang tinggi. The four elements of the randai presentation structure are \pm 20 minutes.

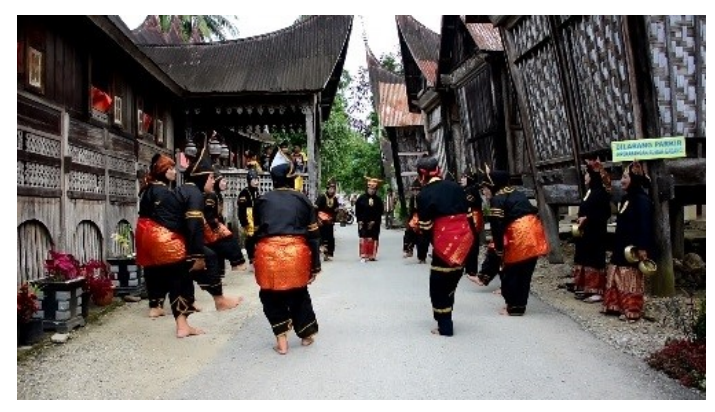

Figure 9

Performing randai packaging art in the yard of Rumah Gadang Gajah Maram

Seribu Rumah Gadang Area of Jorong Lubuk Jaya, Nagari Koto Baru, Sungai Pagu District, Solok Selatan Regency

(Marzam documentation, July 14, 2018)

\section{Conclusions}

The main principle of concern in applying the concept of pseudo traditional arts is not to ignore the art of ancestral heritage that must be preserved. However, it also does not sacrifice the essential elements in the packaging or imitation of traditional art. In this case, the tourism art packaging which is presented in Seribu Rumah Gadang Area of Jorong Lubuk Jaya, Nagari Koto Baru, Solok Selatan Regency, West Sumatra.

Based on researchers' observations, the imitation concept applied by artists does not change the randai structure, but utilizes the element of creativity by incorporating piring dance in the introductory section of randai into the performance arena, and perform only footage of the Bujang Selamat story. Thus, traditional randai performances which usually take 2 to 3 hours, by applying the traditional imitation art concept without neglecting the essential elements in the imitation, marking the tourism packaging art in Seribu Rumag Gadang Area area can take place in \pm 20 minutes. 


\section{Acknowledgments}

This research is fully supported by Affiliation Research Grant.

\section{References}

Anjasuari, Ni Wayan Trisna; Sumadi, K. W., \& I Ketut Arta. (2017). Pertunjukan Tari Barong sebagai Atraksi Wisata di Desa Pakraman Kedewatan Kecamatan Ubud Kabupaten Gianyar. Jurnal Penelitian Agama Hindu, 1(1), 123-128. Retrieved from http://ejournal.ihdn.ac.id/index.php/JPAH

Firdaus. (2009). Kerajaan Alam Surambi Sungai Pagu Ikua Darek Kerajaan Minangkabau (http://lppbifiba.blogspot.co.id/2009/01/kerajaan-alam-surambi-sungai-pagu-ikua.html). Retrieved from http://lppbifiba.blogspot.co.id/2009/01/kerajaan-alam-surambi-sungai-pagu-ikua.html

Indrayuda; Muasri, H., \& Sexri Budiman. (2013). Randai Suatu Aktivitas Kesenian dan Media Pendidikan Tradisional. Padang: Dinas Kebudayaan dan Pariwisata Provinsi Sumatera Barat. UPTD Taman Budaya.

Kuswarsantyo. (2007). Pengambangan Seni Pertunjukan Langen Mandrawanara sebagai Aset Pariwisata di Desa Sembungan Kabupaten Bantul. Http://Download.Portalgaruda.Org/Article.Php, 5(2), 119-132.

Maestro Esy; Marzam. (2018). The Concept and Meaning of Gandang Sarunai Music as Reflected Through The Social and Cultural Activities of The Alam Surambi Sungai Pagu Community of South Solok District, West Sumatra. In Atmazaki (Ed.), Advances in Social Science, Education and Humanities Research (ASSEHR), Sixth International Conference on Languages and Arts (ICLA) (Vol. 148, pp. 263-267). Atlantis Press. Retrieved from https://www.atlantis-press.com/proceedings/icla-17/publishing

Moleong, L. J. (2012). Metode Penelitian Kualitatif (Edisi Revisi). Bandung: Remaja Rosdakarya.

Wendy Hs. (2014). Dramaturgi Teater Rakyat Randai di Minangkabau. Jurnal Kajian Seni, 01(01), 32-47. 